\title{
HEINONLINE
}

Citation: 81 S. Cal. L. Rev. 877 2007-2008

Content downloaded/printed from

HeinOnline (http://heinonline.org)

Wed Jun 6 12:13:03 2012

-- Your use of this HeinOnline PDF indicates your acceptance of HeinOnline's Terms and Conditions of the license agreement available at http://heinonline.org/HOL/License

-- The search text of this PDF is generated from uncorrected OCR text.

-- To obtain permission to use this article beyond the scope of your HeinOnline license, please use:

https://www.copyright.com/ccc/basicSearch.do?

\&operation $=$ go\&search Type $=0$

\&lastSearch $=$ simple\&all=on\&titleOrStdNo=0038-3910

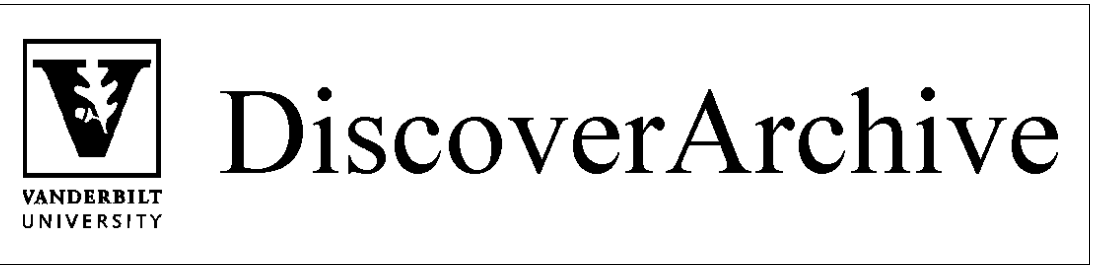

Retrieved from DiscoverArchive,

Vanderbilt University's Institutional Repository

This work was originally published in

81 S. Cal. L. Rev. 877 2007-2008 


\title{
ARTICLES
}

\section{CARHART, CONSTITUTIONAL RIGHTS, AND THE PSYCHOLOGY OF REGRET}

\author{
CHRIS GUTHRIE ${ }^{*}$
}

\begin{abstract}
In Gonzales v. Carhart, the Supreme Court upheld the Partial-Birth Abortion Ban Act. In so doing, the Court used the prospect of regret to justify limiting choice. Relying on empirical evidence documenting the four ways in which regret actually operates, this Article argues that the Court's analysis reflects a fundamental misunderstanding of the psychology of regret. By exposing the Court's misunderstanding of this emotion, this Article seeks to minimize the most significant risk posed by the Carhart decision: that states will use the prospect of regret to justify additional constraints not only on the abortion right but also on other rights protected by the Constitution.
\end{abstract}

\section{INTRODUCTION}

Does the prospect of regret justify limiting choice? Last year, the Supreme Court answered this question affirmatively when it upheld the Partial-Birth Abortion Ban Act in Gonzales v. Carhart. ${ }^{1}$ Writing for a 5-4 majority, Justice Kennedy based the Court's decision, in part, on what

* Associate Dean for Academic Affairs \& Professor of Law, Vanderbilt Law School. For comments on earlier drafts, I thank Jeremy Blumenthal, Mark Brandon, Rebecca Brown, Jonathan Cardi, Doni Gewirtzman, Tracey George, John Goldberg, Joanna Grossman, Brad Joondeph, Terry Maroney, Greg Mitchell, Robert Pushaw, Jeffrey Rachlinski, Suzanna Sherry, and Tom Ulen. For research and library assistance, I thank DeNae Thomas and Michael Jackson.

1. Gonzales v. Carhart, 127 S. Ct. 1610 (2007). 
commentators have called "the most startling passage in the opinion"2 and "a major departure from how the court has framed the abortion issue for the past 34 years": 3 "While we find no reliable data to measure the phenomenon, it seems unexceptionable to conclude some women come to regret their choice to abort the infant life they once created and sustained. Severe depression and loss of esteem can follow." 4

2. Jeffrey Toobin, Five to Four, NEW YORKER, June 25, 2007, at 35. See also Tony Mauro, Kennedy Swings, Abortion Rights Take Hit, Legal TIMES, Apr. 23, 2007, at 8, 8 (observing that the Court "has introduced wrenching and controversial new language into the abortion debate").

3. Linda Greenhouse, Adjudging a Moral Harm to Women from Abortions, N.Y. TIMES, Apr. 20,2007 , at $\mathrm{A} 18$.

4. Carhart, $127 \mathrm{~S}$. Ct. at 1634 (internal citation omitted). In its rather muddled analysis, the Court observed that Congress enacted the Partial-Birth Abortion Ban Act to promote two governmental interests: (1) respect for the dignity of human life and (2) respect for the integrity and ethics of the medical profession. Regret, the Court contended, is relevant to both.

With regard to the former state interest, the Court concluded that the Act promotes respect for the dignity of human life by honoring a woman's love for her unborm child:

Respect for human life finds an ultimate expression in the bond of love the mother has for her child. The Act recognizes this reality as well. Whether to have an abortion requires a difficult and painful moral decision. While we find no reliable data to measure the phenomenon, it seems unexceptionable to conclude some women come to regret their choice to abort the infant life they once created and sustained.

Id. (internal citations omitted).

With regard to the latter state interest, the Court concluded that the Act promotes respect for the integrity and ethics of the medical profession by acknowledging that even though doctors should provide informed consent to patients regarding the intact $D \& E$ procedure, they might be disinclined to do so because the abortion decision is "so fraught with emotional consequence." Id. As a result, a woman undergoing this procedure is likely to lack important information and thereby experience even greater postabortion regret than she would generally:

It is ... precisely this lack of information concerning the way in which the fetus will be killed that is of legitimate concern to the State. The State has an interest in ensuring so grave a choice is well informed. It is self-evident that a mother who comes to regret her choice to abort must struggle with grief more anguished and sorrow more profound when she learns, only after the event, what she once did not know: that she allowed a doctor to pierce the skull and vacuum the fast-developing brain of her unborn child, a child assuming the human form.

Id. (internal citation omitted).

As Justice Ginsburg notes in her dissent, it seems odd that the Court decides not to compel doctors to disclose this important information to inform choice but instead to uphold the ban on the procedure. See id. at 1648-49 (Ginsberg, J., dissenting) ("The solution the Court approves, then, is not to require doctors to inform women, accurately and adequately, of the different procedures and their attendant risks. Instead, the Court deprives women of the right to make an autonomous choice, even at the expense of their safety."). Indeed, relevant research evidence that is not cited by the dissent shows that postdecision regret is often exacerbated when decision makers believe they had inadequate information to make a decision. See, e.g., Joanne Sheehan et al., Association of Information Satisfaction, Psychological Distress and Monitoring Copying Style with Post-Decision Regret Following Breast Reconstruction, 16 PSYCHO-ONCOLOGY 342, 348 (2007) (finding that women undergoing reconstructive surgery following a mastectomy "who experienced lower satisfaction with information were more likely to experience moderate to strong regret, compared to those experiencing no regret"); Jo Ellen Stryker et al., Understanding the Decisions of Cancer Clinical Trial Participants to Enter Research Studies: Factors Associated with Informed Consent, Patient Satisfaction, and Decisional Regret, 63 PATIENT EduC. \& COUNSELING 104, 108 (2006) (finding, in a study of informed consent among patients making the difficult decision to participate in a clinical cancer trial, that 
Writing for the dissent, Justice Ginsburg called the Court's invocation of postabortion regret an "antiabortion shibboleth." In contrast to Justice Kennedy, who relied on affidavits from women describing their feelings of postabortion regret, ${ }^{6}$ Justice Ginsburg cited a litany of scientific studies finding "no reliable evidence" to support the existence of this phenomenon. ${ }^{7}$

Nonetheless, the Court's regret analysis in Carhart has now become "part of Supreme Court doctrine." 8 Indeed, leading constitutional law scholar Jack Balkin described the Court's privileging of postabortion regret over preabortion choice as "the big news about Gonzales v. Carhart.""

But there might be bigger news yet: the impact of the Court's regret analysis could extend well beyond partial-birth abortion claims (as in Carhart) to abortion rights claims more generally (à la Planned Parenthood of Southeastern Pennsylvania v. Casey ${ }^{10}$ and Roe v. Wade ${ }^{11}$ ). In Carhart, after all, the Court relied on claims of regret arising not from partial-birth (or "intact D \& E") abortions specifically but from abortion generally. Thus, it seems likely that state legislatures will use Carhart's regret analysis to impose other restrictions on abortion, including waiting periods, notice obligations, informed consent requirements, etc. Indeed, prior to the decision in Carhart, the South Dakota legislature invoked regret-related concerns to ban abortion in that state, ${ }^{12}$ and commentators

"[p]articipants who reported being well-informed about the clinical trial were significantly less likely to later express regret about their decision to join the trial compared to participants who believed themselves to be less informed").

5. Carhart, 127 S. Ct. at 1648 (Ginsberg, J., dissenting).

6. An antiabortion group called the Justice Foundation collected these affidavits and appended them to its amicus brief on behalf of Sandra Cano. See Brief of Sandra Cano, the Former "Mary Doe" of Doe v. Bolton, and 180 Women Injured by Abortion as Amici Curiae in Support of Petitioner at 1-2, apps. 11-106, Carhart, 127 S. Ct. 1610 (No. 05-380).

7. See Carhart, $127 \mathrm{~S}$. Ct. at 1648 n.7. Ginsburg observed that "'neither the weight of the scientific evidence to date nor the observable reality of 33 years of legal abortion in the United States comports with the idea that having an abortion is any more dangerous to a woman's long-term mental health than delivering and parenting a child that she did not intend to have..."' Id. at $1649 \mathrm{n} .7$ (quoting Susan A. Cohen, Abortion and Mental Health: Myths and Realities, GUTTMACHER POL'Y REV., Summer 2006, at 8, 8).

8. Posting of Jack Balkin to Balkinization, http://balkin.blogspot.com/2007/04/big-news-aboutgonzales-v-carhart.html (Apr. 19, 2007, 14:50 EST).

9. Id.

10. Planned Parenthood of Se. Pa. v. Casey, 505 U.S. 833 (1992).

11. Roe v. Wade, 410 U.S. 113 (1973).

12. See Women's Health and Human Life Protection Act, HB 1215, 81 st Sess. (S.D. 2006) (repealed by voter referendum Nov. 7, 2006); REPORT OF THE SOUTH DAKOTA TASK FORCE TO STUDY ABORTION 21-22 (2005). See also Reva B. Siegel, The New Politics of Abortion: An Equality Analysis of Woman-Protective Abortion Restrictions, 2007 U. ILL. L. REV. 991, 992 (arguing that the South 
suspect that Carhart will empower other state legislatures to act similarly. ${ }^{13}$ If additional restrictions are then challenged in court, lower courts are likely to rely on Carhart's regret analysis to justify these restrictions. As Fred Schauer has observed, the lower courts tend to follow what the Supreme Court has said rather than what it has actually done because when they find themselves "in the pit of actual application .... one good quote is worth a hundred clever analyses of the holding." 14 And if, in turn, the Supreme Court ultimately hears any of these abortion cases, there is reason to believe that the Court would follow its own regret analysis, at least as long as Justice Kennedy remains on the Court.

More importantly, Carhart's regret analysis has the potential to extend well beyond abortion. The Constitution protects several rights that, if exercised, could lead the rights holder to experience regret. For example, a criminal defendant who is unsuccessful in front of a jury of his peers might regret his decision to exercise his right to trial; likewise, a political protestor might regret his emotional tirade in the town square upon learning of the opprobrium brought upon him by his self-expression. In circumstances like these, can the state use the logic of Carhart to prohibit or limit such conduct on the basis of the regret that a rights holder might feel? Can the state, for example, impose limits on the jury trial right or the speech right in order to protect individuals from experiencing regret upon exercising those rights? And if so, will the Court uphold this legislation, as in Carhart, on the basis of that emotion?

At first glance, it might appear unlikely that the Court would extend its regret analysis beyond abortion. Abortion, after all, might be unusual in that it implicates, at least for some people, deeply held moral and religious beliefs. But abortion is hardly alone. Other constitutional issues-including certain speech rights, same-sex sexual behavior, principles of nondiscrimination, and the right to die-also implicate deeply held views. And, as an analytical matter, if the state is deemed to have a legitimate interest in protecting citizens from experiencing regret associated with the exercise of one right, the state should also have an interest in protecting

Dakota ban "gave prominent official endorsement to a claim that has been quietly spreading for decades: that abortion harms women," subjecting them to "emotional and physical injuries").

13. See, e.g., Robin Toner, Abortion Foes See Validation for New Tactic, N.Y. TIMES, May 22, 2007, at A1 (arguing that the Court's regret analysis will "galvaniz[e] anti-abortion forces and set[] the stage for an intensifying battle over new abortion restrictions in the states"). See also Stephanie Simon, Changing Abortion's Pronoun, L.A. TIMES, Jan. 7, 2008, at Al (reporting that the Justice Foundation is currently soliciting affidavits from men documenting postabortion pain as another tool to advocate for limits on abortion).

14. Frederick Schauer, Opinions as Rules, 53 U. CHI. L. REV. 682, 683 (1986) (book review). 
citizens from experiencing regret associated with the exercise of other rights. Thus, the Court might very well extend its regret analysis beyond abortion to the evaluation of other rights claims. ${ }^{15}$

If the Court is going to limit constitutional rights on the basis of the regret a rights holder might experience - as it did in Carhart -it should be sure to understand how regret works. Drawing upon an elaborate body of psychological research that describes the way regret actually operates, this Article finds that the Court misunderstood this emotion in four ways: ${ }^{16}$

First, regret aversion. Because most of us find the prospect of regret unappealing, we tend to factor it into our decisionmaking and take steps to avoid it. This means that an individual contemplating the exercise of a right that might give rise to regret, such as the abortion right, is likely to anticipate that regret and seek to avoid it. ${ }^{17}$

Second, regret overestimation. When contemplating the prospect of regret, we tend to overestimate both its intensity and duration; thus, if we actually experience that regret, we tend to find it significantly less painful and long lasting than we anticipated. This means that an individual contemplating the exercise of a right is likely to find that any regret she ultimately feels, if any at all, is not nearly as bad as expected. ${ }^{18}$

Third, regret dampening. Each of us possesses a set of psychological tactics that enable us to dampen any regret that we actually experience. This means that an individual who exercises a right is likely to take steps to minimize or dampen any regret that she feels. ${ }^{19}$

Finally, regret learning. Even if we find ourselves in the throes of regret, it turns out that regret can serve a powerful function by enabling us to make better choices for ourselves in the future. This means that an individual who exercises a right may have a unique opportunity to learn from any regret she might feel. ${ }^{20}$

To be sure, the Court's concern that abortion might lead to the

15. But see Robert J. Pushaw, Jr., Partial-Birth Abortion and the Perils of Constitutional Common Law, 31 HARV. J.L. \& PUB. POL'Y 519, 567-72 (2008) (arguing that Carhart is not as farreaching as many commentators have asserted).

16. In other words, this Article argues that the Court erroneously relies on what Terry Maroney calls "emotional common sense" rather than empirical research on the emotion of regret. See Terry A. Maroney, Emotional Common Sense as Constitutional Law (June 27, 2008) (working paper, on file with the author).

17. See discussion infra Part II.A.

18. See discussion infra Part ll.B.

19. See discussion infra Part II.C.

20. See discussion infra Part II.D. 
possibility of regret is certainly not unwarranted. But due to regret aversion, regret overestimation, regret dampening, and regret learning, this Article argues that the Court should not abrogate the abortion right or any other Constitutional right on the basis of regret. In short, the Court got regret wrong in Carhart, and it should not extend its regret analysis beyond the four corners of the Carhart decision. ${ }^{21}$

\section{THE SUPREME COURT'S MISUNDERSTANDING OF REGRET}

\section{A. REgREt AVERSION}

Limiting the right to choose on the basis of regret presupposes that a woman contemplating abortion is unable to anticipate the prospect of regret and is somehow caught off guard when she experiences it. In fact, however, there is ample evidence to the contrary, suggesting that the prospect of regret informs and influences decisionmaking.

Regret is among the most common of emotions. ${ }^{22}$ Across a lifetime, we make literally millions of decisions. ${ }^{23}$ Inevitably, some of these turn out badly, and when they do, we may experience regret. ${ }^{24}$ Although there is some dispute over the definition of this seemingly universal emotion, most scholars agree that regret is a painful feeling we experience upon determining that we could have obtained a better outcome if we had decided or behaved differently. ${ }^{25}$

21. This Article adds to the burgeoning literature on law and emotion. For an illuminating overview, see generally Terry A. Maroney, Law and Emotion: A Proposed Taxonomy of an Emerging Field, 30 LAW \& Hum. BeHAV. 119 (2006).

22. See, e.g., Rudiger Bittner, Is It Reasonable to Regret Things One Did?, 89 J. PHIL. 262, 262 (1992) ("We all know regret."); Susan B. Shimanoff, Commonly Named Emotions in Everyday Conversations, 58 PERCEPTUAL \& MOTOR SKILLS 514, 514 (1984) (finding in an analysis of the everyday conversations of college students and married couples that regret was the second most frequently mentioned emotion). But see Len Lecci, Morris A. Okun \& Paul Karoly, Life Regrets and Current Goals as Predictors of Psychological Adjustment, 66 J. PERSONALITY \& SOC. PSYCHOL. 731, 736 (1994) (finding, in a study of life regrets and goals, that subjects reported very few life regrets).

23. See, e.g., Marcel Zeelenberg \& Rik Pieters, $A$ Theory of Regret Regulation 1.0, $17 \mathrm{~J}$. CONSUMER PSYCHOL. 3, 3 (2007) ("The average consumer makes a couple of thousands of decisions daily.") (emphasis added).

24. See, e.g., Thomas Gilovich \& Victoria Husted Medvec, The Experience of Regret: What, When, and Why, 102 PSYCHOL. REV. 379, 379 (1995) ("A lifetime of making choices brings with it the knowledge that at least some actions were ill-considered, some failures to act unwise. For most of us, it also brings with it the realization that some of these unfortunate outcomes could have been avoided.").

25. See, e.g., StUART HAMPShiRe, ThOUght AND ACtion 241 (1960) (defining regret as "a feeling of unpleasure associated with a thought of the past, together with the identification of an object and the announcement of an inclination to behave in a certain way in the future"); JANET LANDMAN, REGRET 36 (1993) (defining regret as "a more or less painful cognitive and emotional state of feeling 
Because regret is both common and painful--because it causes us to "feel a sinking feeling," to fret over "a lost opportunity" and "a mistake... made," and to feel like "kicking" ourselves ${ }^{26}$-we tend to anticipate circumstances in which we might experience $\mathrm{it}^{27}$ and we seek to avoid it if possible. ${ }^{28}$ Faced with the prospect of regret, we commonly defer decisionmaking, ${ }^{29}$ avoid decisionmaking altogether, ${ }^{30}$ or make decisions that appear to offer us a way to sidestep feelings of regret. ${ }^{31}$ Because we tend to anticipate that actions are more likely than inactions to lead to feelings of regret, we are particularly likely to make decisions that maintain the status quo. ${ }^{32}$ In the context of abortion decisionmaking, this suggests that many women will carry to term rather than abort as a way of avoiding anticipated regret.

Researchers from several disciplines employing many different research methods have found a wealth of empirical evidence demonstrating

sorry for misfortunes, limitations, losses, transgressions, shortcomings, or mistakes"); David E. Bell, Reply, Putting a Premium on Regret, 31 MGMT. SCI. 117, 117 (1985) ("Regret is created by a comparison between the actual outcome and that outcome that would have occurred had the decision maker made a different choice."); George Greenberg \& Mary FitzPatrick, Regret as an Essential Ingredient in Psychotherapy, in PSYCHOTHERAPY AND THE REMORSEFUl PATIENT 35, 35 (E. Mark Stern ed. 1988) (defining regret as "the unpleasant feeling associated with some action or inaction a person has taken which has led to a state of affairs that he or she wishes were different").

26. Ira J. Roseman, Cynthia Wiest \& Tamara S. Swartz, Phenomenology, Behaviors, and Goals Differentiate Discrete Emotions, 67 J. PERSONALITY \& SOC. PSYCHOL. 206, 217 tbl.11 (1994).

27. See, e.g., Barry SCHWARTZ, The ParadoX OF ChOICE: Why MORE IS LeSS 158 (2004) ("[T]he prospect of regret is an important cause of many decisions. People will make choices with the anticipation of regret firmly in mind.").

28. See infra notes $33-45$ and accompanying text.

29. See generally, e.g., Ted O'Donoghue \& Matthew Rabin, Choice and Procrastination, 116 Q.J. ECON. 121 (2001) (exploring our tendency to procrastinate when facing unpleasant decisions).

30. See, e.g., SCHWARTZ, supra note 27 , at 159 (observing that one "effect that the desire to avoid regret can have is to induce people not to act at all'); Jane Beattie et al., Psychological Determinants of Decision Attitude, 7 J. BEHAV. DECISION MAKING 129 (1994) (providing experimental evidence showing that anticipated regret can lead to decision avoidance).

31. See infra notes $33-45$ and accompanying text. In fact, scholars have developed an entire decision theory-a rival to expected utility or rational choice theory-based on anticipated regret or regret aversion. Efforts to develop a decision theory based on regret began as early as the 1950s. See, e.g., Leonard J. Savage, The Foundations of Statistics 163-71 (Dover Publ'ns 1972) (1954) (proposing a "minimax rule" intended to recommend courses of action with the smallest possible downside). "Modern" regret theory, however, emerged in early 1980s, when it was developed by three decision theorists. See David E. Bell, Regret in Decision Making Under Uncertainty, 30 OPERATIONS RES. 961 (1982); Graham Loomes \& Robert Sugden, Regret Theory: An Alternative Theory of Rational Choice Under Uncertainty, 92 ECON. J. 805 (1982).

32. See, e.g., Thomas Gilovich, Victoria Husted Medvec \& Serena Chen, Commission, Omission, and Dissonance Reduction: Coping with Regret in the "Monty Hall" Problem, 21 Personality \& SOC. PSYCHOL. BULL. 182, 183 (1995) (reporting that studies "indicate that people believe they would regret a negative outcome that stemmed from an action more than an equivalent outcome that stemmed from an inaction"). 
that we seek to minimize or avoid regret. When making ordinary, everyday decisions-like deciding what goods to buy, ${ }^{33}$ what investments to make, ${ }^{34}$ whether to play the lottery, ${ }^{35}$ and how to negotiate ${ }^{36}$ - we seek to minimize regret. Likewise, when making more consequential decisions involving our health and well-being and the health and well-being of others, we also tend to make regret-minimizing decisions. ${ }^{37}$ For example, researchers have

33. See, e.g., J. Jeffrey Inman \& Leigh McAlister, Do Coupon Expiration Dates Affect Consumer Behavior?, 31 J. MARKETING RES. 423 (1994) (finding, based on a review of coupon redemption behavior, that anticipated regret may explain the increase in coupon redemptions prior to coupon expiration dates); Kathleen N. Lemon, Tiffany Barnett White \& Russell S. Winer, Dynamic Customer Relationship Management: Incorporating Future Considerations into the Service Retention Decision, J. MARKETING, Jan. 2002, at 1, 12 (finding that "anticipated future regret significantly influences the customer's decision to keep or drop the service"); Allen R. McConnell et al., What If I Find It Cheaper Someplace Else?: Role of Prefactual Thinking and Anticipated Regret in Consumer Behavior, 17 PSYCHOL. \& MARKETING 281 (2000) (finding that the prospect that an item will be priced lower in the future can prevent customers from purchasing it and that price guarantees can minimize this effect); Itamar Simonson, The Influence of Anticipating Regret and Responsibility on Purchase Decisions, $19 \mathrm{~J}$. CONSUMER RES. 105 (1992) (finding evidence that the prospect of regret influences brand purchase decisions, among others).

34. See, e.g., Hersh M. Shefrin \& Meir Statman, Explaining Investor Preference for Cash Dividends, 13 J. FIN. ECON. 253 (1984) (analyzing investors' preference for cash dividends over stock dividends). See also Chinmoy Ghosh, A Regret-Theoretic Explanation of Corporate Dividend Policy, 20 J. BUS. FIN. \& ACCT. 559 (1993) (examining financial managers' behavior from a regret aversion perspective). But see Jeffrey J. Bailey \& Chris Kinerson, Regret Avoidance and Risk Tolerance, FIN. COUNSELING \& PLANNING, 2005 Issue 1, at 23, 26-27 (finding that experienced regret but not anticipated regret influenced hypothetical investment decisions).

35. See Paschal Sheeran \& Sheina Orbell, Augmenting the Theory of Planned Behavior: Roles for Anticipated Regret and Descriptive Norms, 29 J. APPLIED SOC. PSYCHOL. 2107, 2133 (1999) (finding that anticipated regret increases intentions to play the lottery); Marcel Zeelenberg \& Rik Pieters, Consequences of Regret Aversion in Real Life: The Case of the Dutch Postcode Lottery, 93 ORganizational BeHav. \& HuM. DeCision PROCEsSES 155, 165 (2004) ("The present research has shown, in a series of four studies, that a specific lottery that provides [feedback] information to their (potential) players, the Postcode Lottery, may evoke anticipations of regret and that these anticipations may hence influence participation decisions.").

36. See, e.g., Chris Guthrie, Better Settle Than Sorry: The Regret Aversion Theory of Litigation Behavior, 1999 U. ILL. L. REV. 43, 73-79 (providing evidence that the opportunity to minimize postdecision regret induces litigants to settle rather than try cases); Chris Guthrie, Panacea or Pandora's Box?: The Costs of Options in Negotiation, 88 lowA L. REV. 601, 636-38 (2003) (finding that subjects deemed negotiators who had to reject options more regretful than those who did not); Russell Korobkin, Inertia and Preference in Contract Negotiation: The Psychological Power of Default Rules and Form Terms, 51 VAND. L. REv. 1583, 1587-91 (1998) (providing experimental data showing that anticipated regret may explain negotiators' preference for default terms in contract negotiations); Richard P. Larrick \& Terry L. Boles, Avoiding Regret in Decisions with Feedback: A Negotiation Example, 63 Organizational Behav. \& Hum. Decision Processes 87, 94 (1995) (finding regret aversion in an employment negotiation exercise); Marcel Zeelenberg \& Jane Beattie, Consequences of Regret Aversion 2: Additional Evidence for Effects of Feedback on Decision Making, 72 Organizational Behav. \& HUM. Decision Processes 63, 69-71 (1997) (finding that anticipated regret influenced subjects' negotiation behavior in an ultimatum game).

37. But see Vered Murgraff et al., Regret Is What You Get: The Effects of Manipulating Anticipated Affect and Time Perspective on Risky Single-Occasion Drinking, 34 ALCOHOL \& 
found that anticipated regret induces us to diet, ${ }^{38}$ exercise, ${ }^{39}$ seek vaccinations, ${ }^{40}$ undergo medical procedures, ${ }^{41}$ drive safely, ${ }^{42}$ engage in environmentally protective behavior, ${ }^{43}$ and practice safe sex. ${ }^{44}$ In short,

ALCOHOLISM 590, 598 (1999) (finding that anticipated affect-including, but not limited to, anticipated regret—did not reduce subjects' intentions to engage in "risky single-occasion drinking").

38. See, e.g., Andrew Steptoe et al., Psychological and Social Predictors of Changes in Fruit and Vegetable Consumption Over 12 Months Following Behavioral and Nutrition Education Counseling, 23 HEALTH PSYCHOL. 574 (2004) (finding that short-term changes in anticipated regret and other psychological variables predicted longer-term changes in fruit and vegetable consumption); Andrew Steptoe et al., Sociodemographic and Psychological Predictors of Changes in Dietary Fat Consumption in Adults With High Blood Cholesterol Following Counseling in Primary Care, 19 HEALTH PSYCHOL. 411,417 (2000) ("We found that patients reporting high anticipated regret showed larger dietary changes than those who anticipated little regret about not taking action.").

39. See, e.g., Charles Abraham \& Paschal Sheeran, Acting on Intentions: The Role of Anticipated Regret, 42 BRIT. J. SOC. PSYCHOL. 495 (2003) (finding that anticipated regret promoted consistency between intent to exercise and actual behavior); Charles Abraham \& Paschal Sheeran, Deciding to Exercise: The Role of Anticipated Regret, 9 BRIT. J. HEALTH PSYCHOL. 269, 275 (2004) (finding that "contemplating anticipated regret ... result[s] in stronger intentions to exercise").

40. Gretchen B. Chapman \& Elliot J. Coups, Emotions and Preventive Health Behavior: Worry, Regret, and Influenza Vaccination, 25 HEALTH PSYCHOL. 82, 85 (2006) (finding that people are more likely to seek flu vaccinations based on anticipated regret and worry than on their perceived risk of actually contracting the flu).

41. See, e.g., Tjeerd Tymstra, The Imperative Character of Medical Technology and the Meaning of "Anticipated Decision Regret," 5 INT'L J. TECH. ASSESSMENT HEAlTH CARE 207, 211 (1989) (finding that "[p]reventing feelings of regret appears to be a motive for undergoing [in vitro fertilization]"). Anticipated regret appears not only to influence patients' decisions, but also the decisions of health care providers. See, e.g., Christopher C. Colenda et al., Anticipated Regret Associated with Treatment Decisions for Agitated Dementia Patients, 3 AM. J. GERIATRIC PsYCHIATRY 68,72 (1995) (finding that physicians anticipated significant regret if they failed to order some type of treatment or intervention and patients were subsequently harmed). See also Alvan R. Feinstein, The "Chagrin Factor" and Qualitative Decision Analysis, 145 ARCHIVES INTERNAL MED. 1257, 1257 (1985) ("Since the relative magnitudes of chagrin will differ for different types of wrong results, a customary clinical strategy is to choose the option whose wrong result will cause the least chagrin."); Cheryl B. Travis, Raymond H. Phillipi \& Bruce E. Tonn, Judgment Heuristics and Medical Decisions, 13 Patient Educ. \& Counseling 211, 215 (1989) (proposing regret avoidance as one possible explanation for clinical treatment decisions).

42. Dianne Parker, Antony S.R. Manstead \& Stephen G. Stradling, Extending the Theory of Planned Behaviour: The Role of Personal Norm, 34 BRIT. J. SOC. PSYCHOL. 127, 134 (1995) ("[T]he more respondents anticipated feeling regret ... the less likely they [are] to report intentions to [commit a risky driving violation]."). See also Dianne Parker, Stephen G. Stradling \& Antony S.R. Manstead, Modifying Beliefs and Attitudes to Exceeding the Speed Limit: An Intervention Study Based on the Theory of Planned Behavior, 26 J. APPLIED SOC. PSYCHOL. 1, 14 (1996) (reporting that viewers of an anticipated-regret video described more negative attitudes toward speeding).

43. Florian G. Kaiser, A Moral Extension of the Theory of Planned Behavior: Norms and Anticipated Feelings of Regret in Conservationism, 41 PERSONALITY \& INDIVIDUAL DifFERENCES 71 (2006) (finding that anticipated feelings of "moral regret" induce conservation and other environmentally friendly conduct).

44. See René Richard, Joop van der Pligt \& Nanne de Vries, Anticipated Affective Reactions and Prevention of AIDS, 34 BRIT. J. SOC. PSYCHOL. 9, 16-17 (1995) (refraining from casual sex and use of condoms); René Richard, Nanne K. de Vries \& Joop van der Pligt, Anticipated Regret and Precautionary Sexual Behavior, 28 J. APPLIED SOC. PSYCHOL. 141 l, 1418-22 (1998) (use of condoms); 
"[o]ur most consequential choices-whether to marry, have children, buy a house, enter a profession, move abroad-are often shaped by how we imagine our future regrets." 45

This means that a woman contemplating abortion is likely to anticipate the possibility that she will experience regret upon terminating her pregnancy. Because she knows that regret is an unpleasant emotion, she is likely to avoid it if she can. This is not to say, of course, that regret is the only emotion she is likely to anticipate; in many circumstances, for example, she might also anticipate feeling relief when she completes the abortion procedure. This is also not to say that abortion is the only potential source of regret in these circumstances; for example, she might also anticipate feeling regret if she carries to term. For purposes of the argument developed in this Article, the point is that we can reasonably expect that a woman making the abortion choice, or any individual making the choice to exercise a presumed constitutional right, is likely to factor the prospect of regret into her decisionmaking and to try to avoid experiencing it if she can. The Supreme Court's presupposition in Carhart that a woman is unable to anticipate the prospect of postabortion regret is belied by the research on regret aversion.

\section{B. REGRET OVERESTIMATION}

A woman contemplating abortion is likely not only to anticipate the prospect of regret, but also to overestimate its potential impact. The regret she anticipates feeling might not materialize at all, but even if it does, it is likely that it will not be nearly as bad as she imagines it would be.

Psychologists have discovered that we are often unable to predict how an event will make us feel. In more technical terms, our "predicted utility" (what we expect) is often quite different from our "experienced utility" (what we experience at the time of the event) and our "retrospective utility" (how we feel after the event has occurred). ${ }^{46}$

René Richard, Joop van der Pligt \& Nanne de Vries, Anticipated Regret and Time Perspective: Changing Sexual Risk-Taking Behavior, 9 J. BEHAV. DecisION MAKING 185, 196 (1996) (finding that "those who focused on their anticipated, post-behavioral feelings expressed stronger expectations to use condoms in future sexual interactions, and that these respondents were more consistent condom users in the five months following the experimental manipulation."); René Richard \& Joop van der Pligt, Factors Affecting Condom Use Among Adolescents, $1 \mathrm{~J}$. COMMUNITY \& APPLIED SOc. PSYCHOL. 105 (1991) (use of condoms); P. van Empelen et al., The Additional Value of Anticipated Regret and Psychopathology in Explaining Intended Condom Use Among Drug Users, 13 AIDS CARE 309, 316 (2001) (condom use by drug users with steady partners).

45. DANIEL GILBERT, STUMBLING ON HAPPINESS 178 (2006).

46. Daniel Kahneman, New Challenges to the Rationality Assumption, 3 LEGAL THEORY 105, 
To be sure, we are not clueless about ourselves. We are actually quite good at predicting whether we will feel positively or negatively about an event, ${ }^{47}$ and we are generally quite good at anticipating the specific emotions we will experience. ${ }^{48}$ When we try to imagine how we would feel upon getting married, for instance, we accurately predict that we will feel positively rather than negatively and that the specific emotions we will experience include happiness. Conversely, when we try to imagine how we would feel upon developing a serious illness, we accurately anticipate that we will feel negatively rather than positively and that the specific emotions we will experience include fear. ${ }^{49}$

What we have difficulty with, however, is predicting how intense and long lasting our emotional reactions will be. We may be able to predict that we will feel happy on our wedding day and fearful when we become ill, but we have difficulty predicting the intensity and duration of these emotions. In other words, we are unable to anticipate the actual impact that events will have on our sense of well-being:

Often people predict correctly the valence of their emotional reactions ("I'll feel good if I get the job") and correctly predict the specific emotions they will experience (e.g., joy). Even when achieving such accuracy, however, it is important for people to predict what the initial intensity of the reaction will be (how much joy they will experience) and the duration of that emotion (how long they will feel this way). It is useful to know that we will feel happy on our first day at a new job, but better to know how happy and how long this feeling will last, before committing ourselves to a lifetime of work as a tax attorney. It is helpful to know that it will be painful to end a long-term relationship, but better to know how painful and whether the pain will last half a second or half a decade. ${ }^{50}$

When anticipating how intense or long lasting our emotional reactions to some event will be, we generally "overestimate the impact [on our]

$107-09$ (1997).

47. Timothy D. Wilson \& Daniel T. Gilbert, Affective Forecasting, 35 ADVANCES EXPERIMENTAL SOC. PSYCHOL. 345, 347 (2003) [hereinafter Wilson \& Gilbert, Affective] (observing that "[i]n general ... people make accurate predictions about which side of the neutral point their emotional experiences will fall, especially if they have had experience in that domain").

48. Id. at 401 (observing that "[p]eople are ... skilled at guessing the specific kinds of emotional reactions they will have").

49. This ability to predict emotions to be experienced extends to regret. See, e.g., Barbara Mellers, Alan Schwartz \& Ilana Ritov, Emotion-Based Choice, 128 J. EXPERIMENTAL PSYCHOL.: GEN. $332,340-41$ (1999) (reporting evidence that subjects were able to predict accurately that they would experience regret).

50. Wilson \& Gilbert, Affective, supra note 47, at 349 (emphasis added). 
emotional lives," imagining that the impact of an event will be much greater than it turns out to be. ${ }^{51}$ This is what psychologists call the "impact bias." 52 Researchers using a variety of methodological approaches have found that we routinely commit impact bias, ${ }^{53}$ particularly when we anticipate feeling negative emotions like regret. ${ }^{54}$

In one illustrative study, researchers asked students enrolled in introductory psychology classes to predict how they would feel if they received a grade one level lower than they expected (for example, an Aminus rather than an expected A) ${ }^{55}$ On a nine-point scale, participants predicted, on average, that they would experience a well-being score of $3.37 .^{56}$ In fact, however, when asked to report their well-being after receiving a lower-than-expected grade, students reported an average wellbeing score of 4.95 , demonstrating that they had predicted they would feel much worse than they actually did. ${ }^{57}$

In another study, researchers took advantage of a student housing lottery on a college campus. ${ }^{58}$ They asked student-subjects to predict how happy or unhappy they would be if they were assigned to each of the available student houses. ${ }^{59}$ On a seven-point scale, the students predicted

51. Id. But see Timothy D. Wilson \& Daniel T. Gilbert, Affective Forecasting: Knowing What to Want, 14 CuRRENT DiRections Psychol. SCI. 131, 131 (2005) [hereinafter Wilson \& Gilbert, Knowing] (acknowledging that people occasionally underestimate intensity and duration).

52. Daniel T. Gilbert, Erin Driver-Linn \& Timothy D. Wilson, The Trouble with Vronsky: Impact Bias in the Forecasting of Future Affective States, in THE WISDOM IN FEELING: Psychological Processes in EMOTIONAL INTElligence 114, 115-17 (Lisa Feldman Barrett \& Peter Salovey eds., 2002). For other attempts to explore the import of the impact bias on legally relevant behavior, see Jeremy A. Blumenthal, Law and the Emotions: The Problems of Affective Forecasting, 80 IND. L.J. 155 (2005); Chris Guthrie \& David Sally, The Impact of the Impact Bias on Negotiation, 87 MARQ. L. REV. 817 (2004).

53. Wilson \& Gilbert, Knowing, supra note 51, at 131 (observing that impact bias "has been found repeatedly in a variety of populations and contexts").

54. See Daniel T. Gilbert et al., Immune Neglect: A Source of Durability Bias in Affective Forecasting, 75 J. PERSONALITY \& SOC. PSYCHOL. 617, 626 (1998) [hereinafter Gilbert et al., Immune Neglect] (observing in three prior studies that "participants overestimated the duration of their negative affect, and they seemed to do so more dramatically and consistently than they overestimated the duration of their positive affect").

55. Roger Buehler \& Cathy McFarland, Intensity Bias in Affective Forecasting: The Role of Temporal Focus, 27 PERSONALITY \& SOC. PSYCHOL. BULL. 1480, 1483-84 (2001).

56. Id. at 1484.

57. Id. To address a couple of methodological problems with this study, the researchers conducted a follow-up study in which they again found that subjects overestimated how negatively they would react to receiving a grade that was below their expectations. Id. at 1484-85.

58. Elizabeth W. Dunn, Timothy D. Wilson \& Daniel T. Gilbert, Location, Location, Location: The Misprediction of Satisfaction in Housing Lotteries, 29 PERSONALITY \& SOC. PSYCHOL. BULL. $1421,1423-25$ (2003).

59. Id. at 1423. 
that their happiness level would be an average of 3.43 if they were assigned to housing they deemed undesirable. ${ }^{60}$ A year later, the researchers asked the same students to indicate how happy or unhappy they actually were. Students assigned to housing they had previously deemed undesirable reported an average happiness level of 5.38, nearly two points higher than predicted. ${ }^{61}$ In fact, "participants assigned to desirable houses were not significantly happier than participants assigned to undesirable houses."

In yet another study, researchers asked participants to predict how they would feel if they experienced the breakup of a romantic relationship, whether initiated by them or by their partner. ${ }^{63}$ On a seven-point scale, they predicted, on average, that their sense of well-being would be 3.89 , near the midpoint of the scale. ${ }^{64}$ Those who broke up, however, reported an average sense of well-being of 5.27 a mere two months after breaking up, indicating a significantly higher level of well-being than had been anticipated. ${ }^{65}$

Finally, in a study focused specifically on regret, ${ }^{66}$ researchers asked study participants to predict how much regret they would feel if they decided to obtain flu vaccinations and nonetheless contracted the flu. ${ }^{67}$ The researchers found a statistically significant "discrepancy between anticipated and experienced regret." 68 On a five-point scale (from "very pleased" to "much regret"), vaccinators predicted they would experience an average regret level of $2.81 .^{69}$ When the researchers asked those same vaccinators to report how much regret they actually felt, however, they reported a regret level of 1.50 , significantly lower than had been expected. ${ }^{70}$ Importantly, "[t]he same results were obtained if the analysis was limited to only those participants who reported getting the flu-

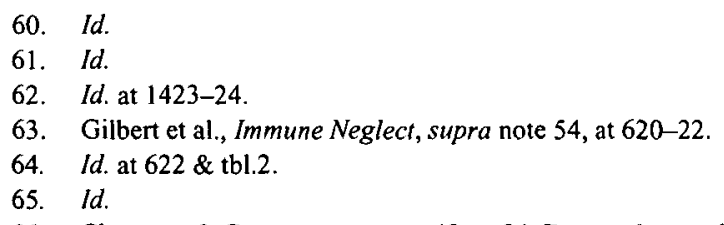

66. Chapman \& Coups, supra note 40 , at 84 . For another study on the impact bias and regret, see Daniel T. Gilbert et al., Looking Forward to Looking Backward: The Misprediction of Regret, 15 PSYCHOL. SCI. 346 (2004) [hereinafter Gilbert et al., Looking] (finding, in two studies, that we commit impact bias when anticipating how much regret we will feel following a "near miss," like just missing the subway).

67. Chapman \& Coups, supra note 40 .

68. Id. at 86 . Note that the nonvaccinators, in contrast to the vaccinators, were able to predict how much regret they would experience. Id. The researchers suggest that the difference between vaccinators and nonvaccinators might be a product of the fact that vaccination is an active intervention, while foregoing vaccination is an inactive embrace of the status quo. $I d$. at 88 .

69. Id. at 85 tbl.2.

70. Id. 
presumably the event that would trigger experienced regret."71

In short, researchers have found that we overestimate the emotional impact of all kinds of life events, including "romantic breakups, personal insults, sports victories, electoral defeats, parachute jumps, failure to lose weight, reading tragic stories, and learning the results of pregnancy and HIV tests." 72 This seems true even with regard to such uncommon and tragic events as "losing a child in a car accident, being diagnosed with cancer, [or] becoming paralyzed." "73 Indeed, experts greatly overestimated the number of New York City residents who would suffer lingering psychological effects following the September 11 th terrorist attacks. ${ }^{74}$

Researchers have identified two primary explanations for impact bias. First, when we anticipate our reactions to a future event we tend to disregard the impact that other life events are likely to have on our sense of well-being at that time. When we focus on how happy we think our marriage will make us, for example, we neglect to consider that problems at work, health issues, and so forth will also have an impact on how we feel. In short, we are prone to what researchers call "focalism"

71. Id. at 86.

72. Wilson \& Gilbert, Affective, supra note 47 , at 353.

73. Gilbert et al., Immune Neglect, supra note 54, at 618. For examples, see Glenn Affleck \& Howard Tennen, Construing Benefits from Adversity: Adaptational Significance and Dispositional Underpinnings, 64 J. PERSONALITY 899, 901-02 (1996) (identifying several studies including the survivors of "a wide array of medical problems for which nearly all or more than a majority of informants cited benefits or gains from their adversity"); Rebecca L. Collins, Shelley E. Taylor \& Laurie A. Skokan, A Better World or a Shattered Vision? Changes in Life Perspectives Following Victimization, 8 SOC. COGNITION 263, 271 (1990) (reporting that a sample of cancer patients "seemed able to derive more benefit than harm from their experiences"); Jason Riis et al., Ignorance of Hedonic Adaptation to Hemodialysis: A Study Using Ecological Momentary Assessment, 134 J. EXPERIMENTAL PSYCHOL: GEN. 3, 7 (2005) (finding that nonpatients predicted they would experience significantly worse moods than actual patients reported experiencing when undergoing hemodialysis); Peter Suedfeld, Reactions to Societal Trauma: Distress and/or Eustress, 18 POL. PsYCHOL. 849, 858-59 (1997) ("TThe 'bottom line' is that people most commonly put their lives together again and move ahead, many citing greater strength, insight, altruism, and sense of purpose as consequences of their traumatic experience."); Peter A. Ubel et al., Misimagining the Unimaginable: The Disability Paradox and Health Care Decision Making, 24 HEALTH PSYCHOL. S57, S62 (2005) (surveying the research to date and concluding that "[p]eople experiencing chronic illness and disability are happier than what healthy people predict they would be under similar circumstances"). But see Darrin R. Lehman et al., Positive and Negative Life Changes Following Bereavement and Their Relations to Adjustment, $12 \mathrm{~J}$. SOC. \& CLINICAL PSYCHOL. 90 (1993) (reporting skepticism about self-reports of positive life changes following tragedies).

74. See Jerome Groopman, The Grief Industry, NEW YORKER, Jan. 26, 2004, at 30, 33 (reporting that the rates of posttraumatic stress disorder among New Yorkers following September 11 th were but a tiny fraction of the rates predicted by experts).

75. Wilson \& Gilbert, Affective, supra note 47, at 366 ("Events do not occur in a vacuum of course, but in the rich context of many other events in people's lives. By neglecting to consider how much these other events will capture their attention and influence their emotions, people overestimate 
"focusing illusion."76 Second, researchers have found that we underestimate the extent to which we possess a "psychological immune system"77 that allows us to adapt to life experiences. Upon experiencing an event, we "inexorably explain and understand events that were initially surprising and unpredictable, and this process lowers the intensity of emotional reactions to the events." 78 In advance, however, we do not anticipate this because the processes of the psychological immune system operate mostly at an unconscious level. ${ }^{79}$ This is particularly so when we face an event-like getting divorced, losing a job, or perhaps terminating a pregnancy - that we anticipate will have a significant negative impact on our well-being. In those circumstances, our psychological immune system kicks into overdrive, working much harder to rationalize or dampen the negative impact of such events. ${ }^{80}$ Ironically, this means that minor annoyances often have a more pronounced effect on our well-being than major life events. ${ }^{81}$ In other words, "it is sometimes more difficult to achieve a positive view of a bad experience than of a very bad experience." $" 82$

For a woman anticipating regret following an abortion, the import of the impact bias is clear. Because she is unlikely to anticipate the impact that other aspects of her life, including friends, family, and work, will have on her well-being, and because she is probably unaware that her psychological immune system will diminish any regret she experiences, she is likely to find that her actual experience of that regret is not nearly as bad as expected. Regret, in short, is "a bit of a boogeyman" in that it tends to "loom[ ] larger in prospect than it actually stands in experience." 83

This account is consistent with three related research findings. First, researchers have found that most of us have something akin to a happiness

the impact of the focal event.")

76. David A. Schkade \& Daniel Kahneman, Does Living in California Make People Happy? A Focusing Illusion in Judgments of Life Satisfaction, 9 PSYCHOL. SCI. 340 passim (1998).

77. Wilson \& Gilbert, Knowing, supra note 51, at 133.

78. Wilson \& Gilbert, Affective, supra note 47, at 371 .

79. See, e.g., Wilson \& Gilbert, Knowing, supra note 51, at 133 ("A feature that all these defenses have in common is that they are largely unconscious, and in fact are more effective by operating behind the mental scenes."). Wilson and Gilbert describe the tendency not to anticipate the operation of the psychological immune system as "immune neglect." Id.

80. See, e.g., GILBERT, supra note 45 , at 181 ("Intense suffering triggers the very processes that eradicate it, while mild suffering does not ....").

81. See Daniel T. Gilbert et al., The Peculiar Longevity of Things Not So Bad, 15 PsYCHOL. SCI. 14 (2004).

82. GILBERT, supra note 45 , at 181

83. Gilbert et al., Looking, supra note 66, at 349. 
or well-being "set point" from which we do not deviate too far or for too long; that is, genes explain most of the variation in subjective well-being, with external events contributing only marginally. ${ }^{84}$ Second, our set points appear to be set relatively high-in study after study, researchers have found that most of us report high levels of subjective well-being. ${ }^{85}$ Third, even though regret is among the most common of emotions, researchers routinely find that we report surprisingly few life regrets. ${ }^{86}$ Lecci and his

84. See, e.g., DAVID LYKKEN, HaPPINESS: What Studies on Twins Show Us ABout NATURE, NURTURE, AND THE HAPPINESS SET POINT 58 (1999) ("Nearly 100 percent of the variation across people in the happiness set point seems to be due to individual differences in genetic makeup!"); Frank Fujita \& Ed Diener, Life Satisfaction Set Point: Stability and Change, 88 J. Personality \& Soc. PSYCHOL. 158, 162 (2005) (finding less long-term stability in life satisfaction ("LS") scores than predicted but concluding nonetheless that "there appears to be a 'soft baseline' for LS, with people fluctuating around a stable set point that nonetheless does move for about a quarter of the population"); David Lykken \& Auke Tellegen, Happiness Is a Stochastic Phenomenon, 7 PsychOL. SCI. 186, 188 (1996) (finding, based on a study of twins, that $80 \%$ of the variance in well-being is a product of genes). But see Richard E. Lucas et al., Reexamining Adaptation and the Set Point Model of Happiness: Reactions to Changes in Marital Status, 84 J. PersonaliTy \& SOC. PSYCHOL. 527, 535-36 (2003) (finding that the negative impact of widowhood on well-being can be substantial but noting conservatively that "[o]ne implication of these findings is that long-term levels of [subjective wellbeing] are not solely determined by personality and genetic predispositions") (emphasis added); Richard E. Lucas et al., Unemployment Alters the Set Point for Life Satisfaction, 15 PSYCHOL. SCI. 8, 11-12 (2004) (finding evidence that "unemployment seems to have had a lasting effect on individuals' life satisfaction" but that "the data simply suggest that temperament is not the sole influence on longterm levels of life satisfaction") (emphasis added).

85. Ed and Carol Diener observe that "[i]n every U.S. national survey, most people have reported a positive level of [subjective well-being]." Ed Diener \& Carol Diener, Most People Are Happy, 7 PSYCHOL. SCI. 181, 181 (1996). Likewise, global reports of well-being are high; in one survey, for instance, $86 \%$ of the nations reported a positive (rather than neutral or negative) overall well-being. Id. In short, "most individuals are above neutral" in their sense of well-being, suggesting that "most people are resilient in that they can recover from adversity." Id. at 185.

86. See, e.g., Anne A. Lawrence, Factors Associated with Satisfaction or Regret Following Male-to-Female Sex Reassignment Surgery, 32 ARChIVES SeXUAL BeHAV. 299, 305 (2003) (finding, among a study of people who underwent sex reassignment surgery, that "[n]o participants reported consistent Regret, and only 15 participants (6\%) were sometimes regretful"); Lecci et al., supra note 22, at 736 (finding, in their study of the phenomenology of regret, that "[s]ubjects listed an average of 3.2 goals and 1.9 regrets, although 11 individuals [out of 155] were unable to identify even a single regret, and the modal regret frequency was only one"); Mala Ramanathan \& U.S. Mishra, Correlates of Female Sterilization Regret in the Southern States of India, 32 J. BIOSOC. SCI. 547, 550 (2000) (finding, in an enormous study of women in four Indian states, that only $4.7 \%, 4.3 \%, 8.4 \%$, and $9.6 \%$ regretted sterilization); Sheehan et al., supra note 4, at 345 (finding a "regret" score of only 13.76 on a 100-point scale and that more than $80 \%$ of the respondents reported no or mild regret among women completing reconstructive breast surgery following a mastectomy); Stryker et al., supra note 4, at 107 (finding, among a group of people who made the difficult choice to participate in clinical cancer trials, that "[t]he average level of decisional regret was very low"); Erika Timmer, Gerben J. Westerhof \& Freya Dittman-Kohli, "When Looking Back on My Past Life I Regret . . ": Retrospective Regret in the Second Half of Life, 29 DEATH STUD. 625, 634 (2005) (finding that, even when prompted to reflect on one's past and provide a regret, $14 \%$ of subjects identified no regrets at all); Cynthia M. Torges, Abigail J. Stewart \& Kathi Minor-Rubino, Personality After the Prime of Life: Men and Women Coming to Terms with Regret, 39 J. RES. PERSONALITY 148, 157 (2005) (finding that only $52 \%$ of the participants in their 
colleagues found, for example, that subjects in their study "reported relatively few regrets (a modal frequency of just one)" and that this is "consistent with research showing that the vast majority of individuals report relatively high levels of well-being despite experiencing negative life events." ${ }^{87}$ This research strongly suggests that the vast majority of women who have terminated their pregnancies will experience comparably high levels of well-being and comparably low levels of regret. ${ }^{88}$

\section{REgRET DAMPENING}

In addition to the dampening that occurs naturally through the unconscious operation of our psychological immune system, ${ }^{89}$ we can, and do, consciously deploy other tactics to minimize feelings of regret. ${ }^{90}$ This Article identifies three of the most common regret-dampening tactics: reassessing our decision options, redirecting our attention, and relating our experiences.

\section{Reassessing Decision Options}

When we make a decision and feel regret, we experience "cognitive dissonance." 91 We can reduce this unpleasant feeling by reassessing the

study reported a regret). But see Geoffrey T. Fong et al., The Near-Universal Experience of Regret Among Smokers in Four Countries: Findings from the International Tobacco Control Policy Evaluation Survey, 6 NICOTINE AND TOBACCO RES. 341, 344-45 (2004) (finding that approximately $90 \%$ of smokers regretted smoking); Sara B. Oswalt, Kenzie A. Cameron \& Jeffrey J. Koob, Sexual Regret in College Students, 34 ARCHIVES SEXUAL BEHAV. 663, 666 (2005) (finding that roughly three-quarters of college students in their sample reported at least one regret about prior sexual behavior).

87. Lecci et al., supra note 22 , at 738.

88. For one illustrative study that is on point, see A. Kero, U. Högberg \& A. Lalos, Wellbeing and Mental Growth-Long-Term Effects of Legal Abortion, 58 Soc. SCI. \& MED. 2559, 2568-69 (2004) ("In summary, the pregnancy was found to cause painful feelings in almost all the women, while the abortion at both 4-month and 12-month follow-up was experienced by almost all as a relief and was regarded as the best possible solution. Almost two-thirds reported only positive experiences as sequels of the abortion process, such as a feeling of wellbeing and mental growth at the 1-year follow-up. In conclusion, this study shows that these Swedish women in general are able to make the complex decision to have an abortion without suffering any regret or negative effects 1 year later.").

89. See supra Part II.B. Note also that researchers have found that there is "a consistent temporal pattern to the experience of regret." Gilovich \& Medvec, supra note 24, at 361 . Namely, "[a]ctions produce greater regret in the short term; inactions generate more regret in the long run." Id. Applied to abortion, the initial decision to abort-an action-might generate more regret in the short term; however, in the long run a woman is more likely to feel regret about things she left undone than the things she did.

90. For an attempt to identify tactics to dampen both anticipated and experienced regret, see Zeelenberg \& Pieters, supra note 23, at 11-14. See also J. Jeffrey Inman, Regret Regulation: Disentangling Self-Reproach from Learning, 17 J. CONSUMER PSYCHOL. 19, 22-23 (2007) (critiquing the Zeelenberg \& Pieters framework and advancing additional regret regulation tactics).

91. See generally LEON FeSTINGER, A THEORY OF CoGNITIVE DisSONANCE (1957) (introducing 
decision options we previously faced; in the language of dissonance theory, we can "increas[e] the attractiveness of the chosen alternative and decreas[e] the attractiveness of the rejected alternative. $" 92$

This reassessment process often happens naturally and unconsciously. ${ }^{93}$ In the classic illustration, the psychologist Jack Brehm asked college students to evaluate the desirability of several products, select one of two products identified by the experimenter, and finally, reevaluate the desirability of all of the products. ${ }^{94}$ As predicted, Brehm found that the subjects evaluated the chosen item more favorably and the rejected item less favorably after making the decision than they had before. ${ }^{95}$ This was particularly true following a "difficult" decision in which the subjects were asked to choose between two items they had rated comparably in advance. ${ }^{96}$ Researchers have replicated and extended these results on dissonance reduction in many contexts. ${ }^{97}$

dissonance theory). See also id. at 36 ("[D]issonance is an almost inevitable consequence of a decision ....").

92. Leon Festinger, Introduction, in CONFLICT, DeCISION, AND DissonanCE 1, 5-6 (Robert R. Sears et al. eds., 1964). Other ways to reduce postdecision dissonance include denying responsibility or trivializing the decision. See, e.g., Patrick Gosling, Maxime Denizeau \& Dominique Oberlé, Denial of Responsibility: A New Mode of Dissonance Reduction, 90 J. PERSONALITY \& SOC. PSYCHOL. 722, 724 26 (2006); Linda Simon, Jeff Greenberg \& Jack Brehm, Trivilialization: The Forgotten Mode of Dissonance Reduction, 68 J. PERSONALITY \& SOC. PSYCHOL. 247 (1995). See also Nick Sevdalis \& Flora Kokkinaki, The Differential Effect of Realistic and Unrealistic Counterfactual Thinking on Regret, 122 ACTA PSYCHOLOGICA 111 (2006) (arguing, based on their empirical work, that we can reduce feelings of postdecision regret by focusing on situational rather than personal factors that give rise to a regretted behavior, thereby mitigating our feelings of responsibility and blame); Carsten Wrosch \& Jutta Heckhausen, Perceived Control of Life Regrets: Good for Young and Bad for Old Adults, 17 PSYCHOL. \& AGING 340, 340, 347 (2002) (finding that "attributions of low internal control might serve self-protective functions in older adults and facilitate deactivation of regret" because such attributions "may reduce the perceived responsibility and, thus, may also reduce the negative emotional consequences of failure experience").

93. One potential trigger is "option attachment." See Ziv Carmon, Klaus Wertenbroch \& Marcel Zeelenberg, Option Attachment: When Deliberating Makes Choosing Feel Like Losing, $30 \mathrm{~J}$. CONSUMER RES. 15 (2003). Carmon and his colleagues have found that when we make a decision carefully and deliberatively, we become attached to the foregone option, which leads us in the immediate aftermath of the decision to feel regretful about rejecting that option, which in turn leads us to attempt to reduce dissonance. Id. at 27.

94. Jack W. Brehm, Postdecision Changes in the Desirability of Alternatives, $52 \mathrm{~J}$. ABNORMAL \& SOC. PSYCHOL. 384, 384-85 (1956).

95. Id. at 386 .

96. Id. at 389 .

97. See, e.g., Ryan K. Beasley \& Mark. R. Joslyn, Cognitive Dissonance and Post-Decision Attitude Change in Six Presidential Elections, 22 POL. PSYCHOL. 521 (2001) (finding evidence of reassessment of candidates following election results); Gilovich et al., supra note 32, at 186 (finding that dissonance reduction is greater when people switch choices rather than stay); Nira Liberman \& Jens Förster, Inferences from Decision Difficulty, 42 J. EXPERIMENTAL SOC. PSYCHOL. 290, 296-99 (2006) (finding evidence of "spreading" in finished decisions but not repeatable decisions, which is expected 
This reassessment process can also be a product of conscious design. For example, we can reduce dissonance intentionally by trying to adopt an "action-oriented mindset." 198 In one study illustrating this process, Eddie Harmon-Jones and Cindy Harmon-Jones asked subjects to rate the desirability of various forms of exercise, such as jumping rope and lifting weights. ${ }^{99}$ Then the researchers asked the subjects to choose one of two exercises to perform. ${ }^{100}$ Unbeknownst to the subjects, the researchers assigned some of them to a control group and others to an experimental group. ${ }^{101}$ The researchers attempted to induce the subjects in this latter group to adopt an action-oriented mindset by instructing them to describe in writing at least seven things they could do to improve their performance on the chosen exercise. ${ }^{102}$ Finally, the researchers asked the subjects in both groups to reevaluate the exercises. ${ }^{103}$ Consistent with Brehm's research, the researchers found that all of the subjects increased their evaluation of the chosen option and decreased their evaluation of the rejected option, but this reassessment was even more pronounced among those in the action-oriented mindset group. ${ }^{104}$ In other words, those subjects who focused on how they would implement their decision were likely to inflate their evaluation of the chosen option and deflate their evaluation of the rejected option even more than those subjects in the control group. This means, of course, that when we make a decision and feel regret, we may be able to dampen that regret by focusing on how we will make the most of the decision we have made.

given that dissonance reduction is unnecessary if the decision can be undone); Thomas R. Shultz, Elène Léveillé \& Mark R. Lepper, Free Choice and Cognitive Dissonance Revisited: Choosing "Lesser Evils" Versus Greater "Goods," 25 Personality \& Soc. Psychol. BUll. 40 (1999) (replicating Brehm's results and finding in difficult decisions involving unattractive options that decision makers are particularly likely to inflate their postdecision evaluations of the chosen option). But see Ilana Ritov, The Effect of Time on Pleasure with Chosen Outcomes, 19 J. BeHAV. Decision MAKING 177 (2006) (finding decreased satisfaction with chosen outcomes in the long term, prompting her to question whether postdecision spreading of decision options is long lived). Note that researchers have found not only that we change our attitudes following a decision to support the selected outcome, but also that our memory changes to support our selected outcome. See, e.g., Mara Mather, Eldar Shafir \& Marcia K. Johnson, Misremembrance of Options Past: Source Monitoring and Choice, 11 PSYCHOL. SCI. 132, 137 (2000).

98. Eddie Harmon-Jones \& Cindy Harmon-Jones, Testing the Action-Based Model of Cognitive Dissonance: The Effect of Action Orientation on Postdecisional Attitudes, 28 PERSONALITY \& SOC. PSYCHOL. BULL. 711,714 (2002).

99. Id. at 714-15.

100. Id. at 715 .

101. Id.

102. Id.

103. Id.

104. Id. at $715-17$. 


\section{Redirecting Attention}

A second way we can dampen feelings of postdecision regret is by consciously redirecting our attention away from the negative feelings associated with the decision we have made. For example, we can search out "silver linings" associated with a regretted decision or behavior. ${ }^{105}$ In one instructive study, researchers evaluated the coping behavior of prison inmates housed in two correctional facilities. ${ }^{106}$ The researchers interviewed the inmates to determine whether they had used the silverlining tactic to dampen their regrets. ${ }^{107}$ They found that two-thirds of the inmates had used this coping tactic and that these inmates reported a significant decrease in regret over time and significantly lower levels of regret than other inmates. ${ }^{108}$

We can also redirect our attention toward currently active life goals. As Len Lecci, Morris Okun, and Paul Karoly explain:

Researchers have shown that the incidence and intensity of regretful ruminations can be temporarily minimized when the individual is focused on the pursuit of active responses (i.e., using an active goal as a "distraction")... which in turn may lead to a more permanent suppression of regretful ruminations and greater psychological wellbeing. ${ }^{109}$

Consistent with this observation, Carsten Wrosch and his colleagues found that older adults who focused on future goals experienced lower

105. Gilovich \& Medvec, supra note 24, at 387 (explaining that "people acknowledge that the outcome may have been regrettable, but they mentally offset the regret by identifying a silver lining that consists of how much they profited from the experience as well"). See also Sunghwan Yi \& Hans Baumgartner, Coping with Negative Emotions in Purchase-Related Situations, 14 J. CONSUMER PSYCHOL. 303, 305 (2004) (describing this regret-dampening tactic as "positive reinterpretation"). Note that "reassessing" and "redirecting" can work hand-in-hand as regret-dampening tactics. See, e.g., Gilovich \& Medvec, supra note 24, at 387 ("Identifying a silver lining in a dark cloud can be one way to reduce the cognitive dissonance associated with a negative outcome brought on by a freely chosen action."); Priyali Rajagopal, Sekar Raju \& H. Rao Unnava, Differences in the Cognitive Accessibility of Action and Inaction Regrets, 42 J. EXPERIMENTAL SOC. PSYCHOL. 302, 310 (2006) (identifying the silver lining tactic as a way of reducing dissonance associated with regretted actions).

106. Frenk van Harreveld et al., Inmate Emotion Coping and Psychological and Physical WellBeing: The Use of Crying Over Spilled Milk, 34 CRIM. JUST. \& BEHAV. 697, 700 (2007).

107. Id. at 704 .

108. Id. (reporting that ten participants saw no positive aspects, while the remaining twenty said that they had gained something from the experience). See also Torges et al., supra note 86, at 162 ("People who put the best face on regrets or who come to terms with regret were significantly higher in life satisfaction and recent positive mood...."); Yi \& Baumgartner, supra note 105, at 314 (reporting that subjects used the silver-lining tactic or "positive reinterpretation" to cope with feelings of regret following a purchasing decision).

109. Lecci et al., supra note 22, at 738 (internal citations omitted). 
levels of regret intensity than those who did not. ${ }^{110}$ In short, we can dampen regret both by focusing on the positives rather than the negatives and by looking forward rather than backward.

\section{Relating Experiences}

In addition to reassessing decision options and redirecting our attention, we can also dampen regret by relating or recording our experiences and reactions. In one recent study, researchers asked participants to reflect on the most traumatic event they had experienced. ${ }^{111}$ For each of three days, some of the participants thought privately about the experience, others talked into a tape recorder about the experience, and still others wrote about the experience. ${ }^{12}$ The researchers found, both immediately after the experiment and four weeks later, that the study participants who had spoken or written about this experience reported a greater sense of well-being than those who had merely thought about it. ${ }^{113}$ Although this study did not focus specifically on regret, it did focus on traumatic life experiences, and presumably for some participants, their most traumatic experience was one that induced feelings of regret. Moreover, ample evidence from other settings-including psychotherapy ${ }^{114}$-provides support for the proposition that we can minimize negative affect by talking or writing about it. ${ }^{115}$ In the inmate study described above, for example, researchers found that those who engaged in an "active" coping strategy, such as "talking to fellow inmates or family about their worries," felt significantly less regret than those inmates who engaged in "passive" coping strategies, like "wanting to be left alone, trying to shut out any thoughts, and watching television." 16

Following an abortion, a woman who experiences regret can use each

110. Carsten Wrosch, Isabelle Bauer \& Michael F. Scheier, Regret and Quality of Life Across the Adult Life Span: The Influence of Disengagement and Available Future Goals, 20 PSYCHOL. \& AGING 657,667 (2005).

111. Sonja Lyubomirsky, Lorie Sousa \& Rene Dickerhoof, The Costs and Benefits of Writing, Talking, and Thinking About Life's Triumphs and Defeats, 90 J. PERSONALITY \& SOC. PSYCHOL. 692, 696 (2006).

112. Id. at 696-97.

113. Id. at 699.

114. See Daniel A. Donnelly \& Edward J. Murray, Cognitive and Emotional Changes in Written Essays and Therapy Interviews, 10 J. SOC. \& CLINICAL PSYCHOL. 334, 348 (1991) (reporting that writing about a traumatic event facilitates coping).

115. See also GILBERT, supra note 45 , at 186-87 (observing that "simply writing about a trauma - such as the death of a loved one or a physical assault — can lead to surprising improvements in both subjective well-being and physical health").

116. van Harreveld et al., supra note 106, at 703 . 
of these dampening tactics. She can reassess her original decision options, identifying reasons why abortion was the right decision and why carrying to term was the wrong decision. For example, she might focus on the fact that she avoided the discomfort and pain associated with pregnancy and childbirth $^{117}$ and that she did not become a mother at a time in her life when she was unprepared emotionally or financially to do so. ${ }^{118}$ She can consciously redirect her attention to positive aspects of her decision or to future life goals, like focusing on her education or career. And she can write about her experience in a journal or talk about it with friends, family, or other loved ones. In short, a woman who has terminated her pregnancy can use these regret-dampening tactics to make peace with her decision if, in fact, she feels any regret at all. ${ }^{119}$

\section{REGRET LEARNING}

Despite evidence suggesting that a woman is unlikely to experience intense and long-lasting regret following abortion, ${ }^{120}$ and despite evidence suggesting that there are many tactics she can deploy to dampen any regret she does feel, ${ }^{121}$ some women will no doubt experience lingering and intense feelings of regret upon terminating a pregnancy. These persistent feelings might be harmful, ${ }^{122}$ but they might also present an opportunity to learn and grow. Indeed, some psychotherapists consciously use regret as a tool to enable their clients to make productive changes in their lives. ${ }^{123}$

117. See, e.g., Planned Parenthood of Se. Pa. v. Casey, 505 U.S. 833, 852 (1992) ("The mother who carries a child to full term is subject to anxieties, to physical constraints, to pain that only she must bear.").

118. See, e.g., Roe v. Wade, 410 U.S. 113, 153 (1973) ("Mental and physical health may be taxed by child care. There is also the distress, for all concerned, associated with the unwanted child, and there is the problem of bringing a child into a family already unable, psychologically and otherwise, to care for it.").

119. See Yi \& Baumgartner, supra note 105, at 305, 312-14 (describing "acceptance" as a coping strategy and providing evidence that those who feel regret following a purchase decision experience regret). In contrast to acceptance, we can also minimize our regrets by disengaging from a prior decision or experience that has caused us to feel regret. See, e.g., Wrosch et al., supra note 110, at 66668 (describing the adaptive benefits of disengaging).

120. See supra Part II.B.

121. See supra Part II.C.

122. See, e.g., Markku Jokisaari, Regret Appraisals, Age, and Subjective Well-Being, 37 J. RES. PERSONALITY 487, 497 (2003) (finding that those with greater regrets were more likely to report lower life satisfaction); Lecci et al., supra note 22, at 736 (finding regret associated with lower life satisfaction and depression).

123. See, e.g., Greenberg \& FitzPatrick, supra note 25, at 35-36; Harold H. Mosak, Guilt, Guilt Feelings, Regret, and Repentance, 43 INDIVIDUAL PSYCHOL. 288, 292 (1987) (arguing that therapists should seek to "substitute regret for guilty feeling[s]"); Jeanne Shaw, The Usefulness of Remorse, in PSyChotherapy and the RemORSEFUl PATIENT 77, 78-79 (E. Mark Stern ed. 1989) (contending that 
Researchers have found that experienced regret, like anticipated regret, motivates us to take steps to avoid or at least minimize future regrets. ${ }^{24}$ In one study, for example, Ira Roseman, Cynthia Wiest, and Tamara Swartz asked participants to recall, describe, and respond to a series of questions about events giving rise to certain, specified emotions (namely, fear, sadness, distress, frustration, disgust, dislike, anger, regret, guilt, and shame). ${ }^{125}$ The researchers then analyzed and compared the participants' responses to identify the defining characteristics associated with these different emotions. With regard to regret, they found that participants reported a strong motivation to distance themselves from their prior regrets and to behave differently in the future:

In regret experiences, as predicted, subjects felt a sinking feeling, thought about a lost opportunity and a mistake that they had made, felt like "kicking" themselves and correcting their mistake, actually did something differently, and wanted to get a second chance and improve their performance. Overall, regret seems to be an emotion in which people seek to distance themselves from what they had done previously, for example, by changing their behavior to improve on past performances. ${ }^{126}$

Not only does the experience of regret motivate us to minimize future regret, it can also lead to actual behavioral change. In one study, for

regret or remorse can be a productive emotion in therapy). But see Stanley Rosner, On the Place of Regrets in Psychoanalytic Psychotherapy, 11 PSYCHOANALYSIS \& PSYCHOTHERAPY 86, 87 (1994) (arguing that the fear of confronting one's regrets might impede treatment); Peter Shabad, Fixation and the Road Not Taken, 4 PSYCHOANALYTIC PSYCHOL. 187, 197-200 (1987) (arguing that regret might create resistance to change).

124. Janet Landman et al., Missed Opportunities: Psychological Ramifications of Counterfactual Thought in Midlife Women, 2 J. ADULT DEV. 87, 89 (1995) ("Like pain, counterfactual thought about a regrettable past may serve instructional and motivational purposes-telling us that something is wrong and moving us to do something about it.").

125. Roseman et al., supra note 26, at 208-09.

126. Id. at 213-14. In a follow-up study, Marcel Zeelenberg and his colleagues used a procedure that was similar to the procedure used by Roseman and his colleagues to compare subjects' reports about the experience of regret versus the experience of disappointment-an emotion that Roseman and his colleagues did not include in their study. Marcel Zeelenberg et al., The Experience of Regret and Disappointment, 12 COGNITION \& EMOTION 221, 223-24, 227 (1998). They summarized their results as follows:

On the basis of our findings, the experience of regret can be differentiated from that of disappointment in that the former involves feeling more intensely that one should have known better, thinking about what a mistake one has made, feeling a tendency to kick oneself and to correct one's mistake, and wanting to undo the event and to get a second chance.

$I d$. at 227. In short, regret "motivates one to think about how this event could have happened and how one could change it, or how one could prevent its future occurrence." Id. at 228. See also Arthur W. Blume \& Karen B. Schmaling, Regret, Substance Abuse, and Readiness to Change in a Dually Diagnosed Sample, 23 ADDICTIVE BEHAV. 693, 696 (1998) (finding that experienced regret creates motivation to alter substance use). 
example, researchers explored whether induced feelings of regret would increase the likelihood that subjects would make responsible dietary decisions. ${ }^{127}$ In this study, researchers asked subjects to identify and describe a prior event that gave rise to one of three specified emotions: fear, regret, or responsibility. ${ }^{128}$ Then, the researchers gave all of the subjects a pamphlet entitled, "Not Eating Fiber can KILL," which identified key reasons why young adults should eat a high-fiber diet. ${ }^{129} \mathrm{~A}$ week later, the researchers brought a high-fiber cereal and a low-fiber cereal to class and recorded which of the cereals the subjects chose to eat. Among those who felt regretful, $71 \%$ chose the high-fiber cereal as compared to only $29 \%$ of the responsibility subjects, $3 \%$ of the fear subjects, and $27 \%$ of the subjects in the control group. ${ }^{130}$ Feelings of regret produced more behavioral change than the other felt emotions.

In another study, these same researchers gave subjects a pamphlet describing "Andy," an individual battling malignant melanoma. ${ }^{131}$ Some of the pamphlets attempted to induce feelings of regret-by, for example, indicating that "Andy admitted self-blame because of his poor decision making"-while others attempted to induce other emotions. In the "hope" condition, for example, Andy expressed the desire to get well. ${ }^{132}$ All of the pamphlets concluded by recommending the use of sunscreen. ${ }^{133}$ The following day, three days later, ten days later, and eighteen days later, the researchers asked all of the subjects whether they had used sunscreen on those days. Those who experienced regret were more likely than any of the other subjects to have used sunscreen. ${ }^{134}$ Three days after the experiment, for example, $78 \%$ of the regret subjects-as compared to $25 \%$ of the fear subjects, $29 \%$ of the hope subjects, and $44 \%$ of the challenge subjectsreported applying sunscreen. ${ }^{135}$

Finally, in three studies, researchers found that subjects who experienced regret over a decision were significantly more likely than those who simply felt disappointed about the decision to alter their behavior. In one of these experiments, researchers found that subjects who felt regret

127. Kirsten Passyn \& Mita Sujan, Self-Accountability Emotions and Fear Appeals: Motivating Behavior, 32 J. CONSUMER RES. 583, 587-88 (2006).

128. Id. at 587 .

129. Id.

130. Id. at $588 \mathrm{tbl} .3$.

131. Id. at 585-87.

132. Id. at 585 .

133. Id.

134. Id. at 587 tbl.2.

135. Id. 
changed their future behavior in a lottery; ${ }^{136}$ in the other two experiments, researchers found that subjects were more likely to switch from one service provider - such as a cell phone company or internet provider-to another if they regretted retaining the initial service provider. ${ }^{137}$ Summarizing this work, the researchers explained that these "studies show that regret strongly promotes the tendency to switch to another option or behavioral alternative and that this effect is driven by regret."138 In short, "experienced retrospective regret promotes decisions that make this regret disappear."139

Unfortunately, we do not know as much about the impact of experienced regret on future behavior as we do about other aspects of regret. ${ }^{140}$ What we do know, however, suggests that regret can be powerfully motivating, enabling us to identify mistakes, learn from them, and behave differently in the future. As Barry Schwartz puts it, regret "serves several important functions." 441 Among others, it "may mobilize or motivate us to take the actions necessary to undo a decision or ameliorate some of its unfortunate consequences," and it "may emphasize the mistakes we made in arriving at a decision, so that, should a similar situation arise in the future, we won't make the same mistakes."142

136. Marcel Zeelenberg, J. Jeffrey Inman \& Rik G.M. Pieters, What We Do When Decisions Go Awry: Behavioral Consequences of Experienced Regret, in CONFLICT AND TRADEOFFS IN DECISION MAKING 136, 147-48 (Elke U. Weber et al. eds., 2001) (citing to an unpublished study).

137. See Marcel Zeelenberg \& Rik Pieters, Beyond Valence in Customer Dissatisfaction: A Review and New Findings on Behavioral Responses to Regret and Disappointment in Failed Services, 57 J. Bus. RES. 445, 451-52 (2004); Marcel Zeelenberg \& Rik Pieters, Comparing Service Delivery to What Might Have Been: Behavioral Responses to Regret and Disappointment, 2 J. SERVICE RES. 86, 91-95 (1999).

138. Zeelenberg et al., supra note 136 , at 148-49.

139. Zeelenberg \& Beattie, supra note 36, at 76. But see Rebecca K. Ratner \& Kenneth C. Herbst, When Good Decisions Have Bad Outcomes: The Impact of Affect on Switching Behavior, 96 Organizational Behav. \& Hum. Decision Processes 23, 35 (2005) ("These four studies demonstrate that individuals feel regret when they choose a probabilistically favored option and the outcome is unfavorable. As a result, they are less willing to choose that decision option again in the future, even when they believe that the option is more likely than the alternatives to produce a successful outcome."); Abigail J. Stewart \& Elizabeth A. Vandewater, "If I Had It to Do Over Again...": Midlife Review, Midcourse Corrections, and Women's Well-Being in Midlife, $76 \mathrm{~J}$. PERSONALITY \& SOC. PSYCHOL. 270 (1999) (finding among middle-aged women considering educational or career regrets that regret motivated goal setting but did not necessarily lead to behavioral change).

140. See, e.g., Zeelenberg \& Beattie, supra note 36, at 72 (observing that "[u]ntil now regret research has predominantly focused on the effects of the anticipation of this emotional state on decision making," yet this is "only half of the story"); Zeelenberg et al., supra note 136, at 152 (observing that "there is a paucity of research" addressing "regret effects on behavior in our daily lives"); Zeelenberg \& Pieters, supra note 23 , at 11 ("[T]here is, as yet, little systematic research on regret regulation strategies ....").

141. SCHWARTZ, supra note 27 , at 164 .

142. Id. See also Bailey \& Kinerson, supra note 34, at 26 ("We found that people are less likely to 
To be sure, abortion differs in important ways from dieting, using sunscreen, playing the lottery, or deciding whether to switch a service provider. The fact that those who experienced regret in these instances subsequently altered their behavior suggests, however, that those women who find themselves feeling postabortion regret are also likely to take steps to avoid future related regrets. Among other things, for example, they might select different sexual partners, alter the sexual behavior they engage in with their partners, use birth control, and so on. This means that when the Court constrains the exercise of the abortion right - or any other right, for that matter-it limits not only the right to make a choice but also the opportunity to learn from the very act of choosing.

\section{CONCLUSION}

The Supreme Court's observation in Carhart that some women will experience regret following abortion is unremarkable. Likewise, it would be unremarkable to observe that the decision to act on any number of rights protected by the Constitution might also lead to feelings of regret. What is remarkable, though, is using the prospect of regret to justify limiting a woman's right to choose or any other right ostensibly protected by the Constitution.

This Article has identified four separate, but overlapping, reasons why the Court's regret analysis in Carhart is misguided: regret aversion, regret overestimation, regret dampening, and regret learning. Simply stated, a woman contemplating abortion is likely to anticipate and seek to avoid regret; overestimate its impact on her well-being; take conscious steps to dampen any regret that she feels; and use that regret to make better decisions for herself in the future. This is not to deny that some women, including the women identified in the Justice Foundation's amicus brief in Carhart, experience significant regret following abortion. ${ }^{143}$ Nor is this to

invest in a manner in which they had experienced regret, i.e., the experience of regret with a particular type of investment."); Zeelenberg \& Pieters, supra note 23, at 13 (contending that "regret not only helps us to remember our mistakes and missed opportunities and motivates us to engage in reparative action; by means of mental undoing it also prepares us to behave more appropriately when we are confronted with similar choices in the future").

143. As Jeremy Blumenthal explains:

Women generally experience positive emotions after abortion; indeed, positive emotions are clearly more prevalent than negative emotions. Nevertheless, some women are more at risk than others to negative psychological sequelae: those who pursue abortion for reasons of birth defects in the fetus; younger women; unmarried women without children; women who lack social support; and women who had previously suffered some sort of emotional disturbance or psychological dysfunction.

Jeremy A. Blumenthal, Abortion, Persuasion, and Emotion: Implications of Social Science Research on Emotion for Reading Casey, 83 WASH. L. REV. 1, 10-11 (2008). 
assume that all of us experience regret similarly; in fact, there is evidence suggesting that there are some individual differences in the experience of certain kinds of regrets. ${ }^{144}$ However, the bulk of the empirical evidence on the operation of regret-just like the bulk of the empirical evidence on postabortion well-being cited by Justice Ginsberg in dissent-strongly suggests that most women fare quite well following abortion. For these reasons, the Court was wrong to invoke the prospect of postabortion regret in Carhart, and it should not use regret to impose further limits on abortion or any other constitutional right. ${ }^{145}$

144. See, e.g., SCHWARTZ, supra note 27, at 86-87, 146 ("maximizers" are more likely than "satisficers" to experience regret); Aidan Feeney et al., Is Regret for Inaction Relatively SelfEnhancing?, 19 APPLIED COGNITIVE PSYCHOL. 761 (2005) (finding differences in the experience of regret between high and low self-esteem subjects); Fong et al., supra note 86, at 346 (finding gender and age differences regarding smoking regret); Lucia Mannetti, Antonio Pierro \& Arie Kruglanski, Who Regrets More After Choosing a Non-Status-Quo Option? Post Decisional Regret Under Need for Cognitive Closure, 28 J. ECON. PSYCHOL. 186 (2007) (finding that those with a high "need for cognitive closure" experience more regret than those without); Michelle Renee Monroe et al., The Mildly Depressed Experience More Post-Decisional Regret than the Non-Depressed, $24 \mathrm{~J}$. Soc. \& CLINICAL PSYCHOL. 665 (2005) (finding that the mildly depressed experience greater regret over decisions than the non-depressed); Wrosch \& Heckhausen, supra note 92 (finding age-related differences in the experience of regret); Wrosch et al., supra note 110 (finding age-related differences in the experience of regret).

For more on the importance of taking individual difference into account when undertaking law and social science research, see generally Gregory Mitchell, Why Law and Economics' Perfect Rationality Should Not Be Traded for Behavioral Law and Economics' Equal Incompetence, 91 GEO. L.J. 67 (2002).

145. The argument this Article advances is obviously relevant to the "paternalism debate" raging among behavioral law and economics scholars. See, e.g., Gregory Mitchell, Libertarian Paternalism Is an Oxymoron, 99 Nw. U. L. REv. 1245 (2005); Jeffrey J. Rachlinski, The Uncertain Psychological Case for Paternalism, 97 Nw. U. L. REv. 1165 (2003); Cass R. Sunstein \& Richard H. Thaler, Libertarian Paternalism Is Not an Oxymoron, 70 U. CHI. L. REV. 1159 (2003). As indicated, the author believes that the paternalism embodied in the Carhart decision is misguided, but is not opposed to paternalistic interventions in general-particularly "light" ones. See, e.g., George Loewenstein \& Emily Haisley, The Economist as Therapist: Methodological Ramifications of "Light" Paternalism, 1 Handbook Econ. Methodologies (forthcoming 2008) (proposing light paternalism). 
